\title{
The Implementation of E-Commerce for Micro, Small and Medium Enterprises (MSMES) in Covid 19 Pandemic Era
}

\author{
Ihwana As'ad ${ }^{1 *}$, Muhammad Alwi², Bestfy Anitasari ${ }^{3}$, Alfry Aristo J Sinlae ${ }^{4}$, Fresy \\ Nugroho $^{5}$, Khairul Anwar ${ }^{6}$ \\ ${ }^{1}$ Department of Information Technology, Faculty of Computer Universitas Muslim Indonesia, Makassar - Indonesia \\ ${ }^{2}$ Department of Mechanical Engginering, STITEK Dharma Yadi, Makassar - Indonesia \\ ${ }^{3}$ Department of Nursing, Institute Kesehatan dan Bisnis Kurnia Jaya Persada, Palopo - Indonesia \\ ${ }^{4}$ Department of Computer Science, Faculty Engineering Universitas Katolik Widya Mandira, Kupang - Indonesia \\ ${ }^{5}$ Department of Information Technology, Faculty Science and Technology Universitas Islam Negeri Maulana Malik \\ Ibrahim, Malang - Indonesia \\ ${ }^{6}$ Department of Education and Teacher Training, Institut Agama Islam Tebo, Jambi - Indonesia \\ ${ }^{*}$ Corresponding author. Email: ihwana.asad@umi.ac.id
}

\begin{abstract}
The COVID-19 pandemic has had a huge impact on all sectors of people's lives. One of the sectors that greatly affected was the economic sector. Micro, small, and medium enterprises are one part of the community's economic activities that are trying to stay afloat, although not infrequently some are forced to go out of business. The use of electronic commerce is a step for SMEs to survive. This study uses qualitative methods with descriptive data analysis and is equipped with a literature study. The result shows that the technique of marketing products and services using e-commerce is a survival strategy for MSMEs during the pandemic.
\end{abstract}

Keywords: E-commerce, Micro, Small, Medium Enterprise, Pandemic.

\section{INTRODUCTION}

MSMEs (micro, small, and medium enterprises) constitute the lifeblood of the economic development of a country. In general, MSMEs play the following responsibilities in the national economic system: (1) as the leading reasons of economic growth, (2) as the greatest provider, (3) as leading components in local economic development and community empowerment, (4) as inventors of new markets and sources of innovation, and (5) as a provider to the balance of payments In addition, MSMEs play a vital role in rural economic development, mainly in terms of employment prospects and sources of income for the poor, as well as income distribution and poverty reduction.

According to Tambunan [1] in general, MSMEs have an important role socially and economically in developing countries because: (1) they are widely distributed in rural areas so that they are very important for rural economic development; (2) the ability of MSMEs to absorb significantly the majority of workers; (3) acting as a place for entrepreneurship and skills development businesses, especially in rural areas; and (4) as a source of business opportunities for women.

The existence of the Covid-19 pandemic that has hit the world for almost the last these two years has had an impact on all sectors, especially the economic sector, small and medium businesses. Based on the results of the Katadata Insight Centre (KIC) survey conducted on 206 MSME actors in Jakarta and neighbour city (Jabodetabek), the majority of MSMEs of $82.9 \%$ felt the negative impact of this pandemic and only 5.9\% experienced positive growth. This pandemic condition has even caused $63.9 \%$ of the affected MSMEs to experience a decline in turnover of more than $30 \%$. Only $3.8 \%$ of MSMEs experienced an increase in turnover. The KIC survey also shows that MSMEs have made a number of efforts to maintain their business conditions. They take a number of efficiency measures such as: reducing the production of goods/services, reducing working hours and the number of employees and sales/marketing channels. Even so, there are also MSMEs who take the opposite step, namely adding marketing channels as part of their survival strategy [2]. 
Based on this background, the main purpose of this paper is to examine the survival strategy of SMEs through e-commerce marketing so that they can survive in this pandemic era, with an emphasis on the following three things: (1) the role of SMEs in the national economy, (2) strategies survive the pandemic era; and (3) the importance of marketing strategies, especially through e-commerce.

\section{LITERATURE REVIEW}

The economic recovery continues after the COVID19 pandemic. Research to maintain economic sustainability is now starting to be built again, especially by collaborating with small and medium-sized companies [3]. The surge of this revival resonated in several countries. For example, countries in Latin America [4]. The ginseng country, South Korea, is also echoing an economic revival by adopting e-commerce [5]. Many studies have also been carried out on the economic effects of the pandemic on small-scale entrepreneurs [6]. Several researchers propose solutions and consider the challenges that will be faced [7].

A scientific review that examines the importance of e-commerce in Southeast Asia is proposed to find the best solution [8]. Some researchers even conduct training and mentoring for small and medium scale entrepreneurs to stay afloat [9]. Other researchers propose strategies that need to be carried out to maintain SME business performance [10]. An empirical study on the application of e-commerce was also carried out by the University of Pasundan [11]. In terms of the home industry, an in-depth study has also been carried out [12]. A more in-depth study was conducted in Bogor to see the level of business adoption since the pandemic [13].

From the point of view of culture and cyber law enforcement, the behaviour of online sellers is also carefully studied [14]. Several researchers have proposed adopting e-commerce as the backbone of the business as a solution [15], and they also performed an analysis on online purchasing transactions [16]. The results of the initial study revealed significant growth, but substantial obstacles remain [17]. The readiness of MSMEs is reviewed in terms of business strategy to deal with a prolonged crisis [18]. Several studies have proposed the development of creative industries in Indonesia [19].

\section{METHOD}

The design of this research is descriptive qualitative with a phenomenological approach. Qualitative research aims to understand in depth a phenomenon according to the perspective of the people who experience it [20]. The phenomenological approach used aims to produce an indepth description of the phenomenon from an experience
[21]. In the context of this research, the phenomenon studied is how the implementation of e-commerce by owners of micro, small and medium enterprises (MSMEs) during the COVID-19 pandemic.

The data collection technique is done by looking for primary data and secondary data. Primary data was obtained by conducting in-depth interviews with the managers of each MSME using open-ended questions. In this study, secondary data was also used to complete the primary data. Secondary data obtained through literature searches related to the research concept.

\section{RESULT AND DISCUSSION}

MSMEs play an important role in economic regulation because they support large-scale business units, are able to provide employment and innovate in their products and services so that they are called the lifeblood of the modern economy. MSME actors are required to be able to develop their independence and business potential in the midst of intense business competition. Especially during the COVID-19 pandemic, many MSME units were forced to go out of business because of their inability to compete. In order to survive, MSMEs must be stable and innovative in all areas of their operations including planning, production, finance, marketing and human resource management. Efforts are being made to build a social network which will have implications for promotion and business growth, besides that MSMEs must be able to build a good image and reputation so that they are able to provide satisfactory services to consumers. This effort can be done through the use of digital technology.

Adaptation of digital technology in MSME operational units has become a necessity in the context of the global market. One form of digital technology adoption is the use of social media. In accordance with the results in this study which found that the efforts of MSMEs to survive were even able to reap profits in the midst of a pandemic by adopting e-commerce, namely using social media as a communication medium for marketing and business promotion. The social media used are included in the category of digital marketing communication media, including Facebook, Instagram, Twitter, etc. This type of social media was chosen because it is efficient, effective, interactive, massive, can adapt to the needs of its users and provides convenience and convenience in transacting business online without time limits [22], [23], [24]. In line with this, based on research conducted by As'ad [25] to MSMEs through an online survey, it was found that the use of e-commerce has been shown to provide many advantages such as increased sales and customer revenue. This indicates that with e-commerce they can survive in running their business even though the pandemic is still ongoing. 
The benefits of using e-commerce include cost savings in terms of marketing products and services, improving work processes and efficiency, boosting close relationships with clients, permitting SMEs to compete with large corporations, and providing easy communication and transaction freedom without regard to location or time. However, there are also obstacles faced by MSME unit actors in applying e-commerce, namely the limitations of IT facilities and skilled personnel in the IT field, business unit readiness and security issues [26], [27].

In this study, it was found that MSME actors really hope that the government is serious about building good infrastructure and starting to introduce the internet to people in remote areas because the main key to ecommerce itself is internet technology. Furthermore, MSME actors also raised an important issue, namely the security of personal data, given the demand for personal data to be inputted in the marketplace or other ecommerce sites. Stricter regulations are needed to regulate so that the marketplace can be more responsible for consumer personal data, not to be misused by irresponsible parties, considering that there are still many fake transactions and online shopping scams that make people hesitate to make online transactions. Logistics problems are also a weakness of e-commerce. Logistics generally cannot cover several areas.

\section{CONCLUSION}

The COVID-19 pandemic has caused a significant impact on economic changes for business actors, especially MSMEs, so that $63.9 \%$ experienced a decrease in turnover due to the low level of product sales. To overcome this, E-commerce is here as the best solution for MSMEs to stay afloat in developing their business through online sales during this pandemic.

\section{AUTHORS' CONTRIBUTIONS}

Ihwana As'ad (IA) was the main author in this article. IA and Bestfy Anitasari (BA) have designed introduction, research and collected the data. Then Fresy Nugroho (FN) and Muhammad Alwi (MA) conducted literature review and did the analysis of the data obtained. The conclusion was conclude by Alfry Aristo J Sinlae (AAJS) so this research can be completed properly. Furthermore Khairul Anwar (KA) whose help editing the manuscript. Finally, all the Authors did the deep review and proofread before submitting the manuscript.

\section{ACKNOWLEDGMENTS}

We would like to express our special thanks and gratitude to Rector of Universitas Negeri Makassar, KodeLN
(CEL) and friends who gave us support to carry out this research.

\section{REFERENCES}

[1] T. Tambunan, "Recent evidence of the development of micro, small and medium enterprises in Indonesia," J. Glob. Entrep. Res., vol. 9, no. 1, p. 18, 2019, doi: 10.1186/s40497-018-0140-4.

[2] Katadata, "Digitalisasi UMKM di Tengah Pandemi Covid-19," $\quad$ https://katadata.co.id/, 2020. https://katadata.co.id/umkm.

[3] I. Gregurec, M. Tomičić Furjan, and K. TomičićPupek, "The Impact of COVID-19 on Sustainable Business Models in SMEs," Sustainability, vol. 13, no. 3. 2021, doi: 10.3390/su13031098.

[4] K. A. Stiftung, Post Pandemic Covid-19: Economy recovery, Publicatio. Panama City: ECLAC, 2021.

[5] S. Lee, "E-commerce Adoption and Effects on South Korean SMEs During the Covid-19 Pandemic," Int. J. Appl. Sociol., vol. 11, no. 1, pp. 11-20, 2021, doi: 10.5923/j.ijas.20211101.02.

[6] M. Belitski, C. Guenther, A. S. Kritikos, and R. Thurik, "Economic effects of the COVID-19 pandemic on entrepreneurship and small businesses," Small Bus. Econ., 2021, doi: 10.1007/s11187-021-00544-y.

[7] O. Uvarova and A. Pobol, "SMEs Digital Transformation in the EaP countries in COVID-19 Time: Challenges and Digital Solutions Acknowledgment," p. 68, 2021, [Online]. Available: https://eap-csf.eu/wpcontent/uploads/SMEs-digital-transformation-inthe-EaP-countries-during-COVID-19.pdf.

[8] Z. Abdullah and N. C. Nawi, "an Overview of Covid-19 Impacts on Commercial E-Commerce Platforms in Southeast Asia Region," Int. J. Entrep. Bus. Dev., vol. 04, no. 01, pp. 55-58, 2021.

[9] N. A. Adam and G. Alarifi, "Innovation practices for survival of small and medium enterprises (SMEs) in the COVID-19 times: the role of external support," J. Innov. Entrep., vol. 10, no. 1, p. 15, 2021, doi: 10.1186/s13731-021-00156-6.

[10] M. N. Utomo, I. Ariska, S. R. Pratiwi, and K. Kaujan, "Strategies for Maintaining SMEs Performance During Covid-19 Pandemic," Int. J. Soc. Sci. Bus., vol. 5, no. 1, pp. 34-43, 2021.

[11] M. Ilham and I. Ratnamiasih, "E-Commerce And Competence, Impact On Business Performance: 
Empirical Study On Implementation E-Commerce By Students At Pasundan University," $J$. Accounting, Financ. Taxation, Audit., vol. 3, no. 1 SE-Articles, Mar. 2021, doi: 10.28932/jafta.v3i1.3339.

[12] D. Kurniasih and F. M. Akbar, "E-Commerce Pandemic Covid-19 Home Industries and SMEs," Int. J. Res. Appl. Technol., vol. 1, no. 1, pp. 70-75, 2021, doi: 10.34010/injuratech.v1i1.5640.

[13] K. Oktora, S. P. Lolita, V. Y. Ismail, M. R. Novesar, and A. T. Bon, "E-commerce adoption level in smes since pandemic covid-19 case in bogor, indonesia," Proc. Int. Conf. Ind. Eng. Oper. Manag., vol. 59, pp. 1836-1847, 2020.

[14] R. Setiyawan and S. U. Wicaksana Prakasa, "Indonesian Online Shopping Practices in the COVID-19 Pandemic Era: A Study of Culture and Cyber Security Law," J. Huk. Nov., vol. 12, no. 01, p. 29, 2021, doi: 10.26555/novelty.v12i01.a16944.

[15] Nurlela, "E-Commerce, Solusi di Tengah Pandemi COVID-19," J. Simki Econ., vol. 4, no. 1, pp. 4756, 2021, [Online]. Available: https://jiped.org/index.php/JSE.

[16] N. A. Rakhmawati, A. E. Permana, A. M. Reyhan, and H. Rafli, "Analisa Transaksi Belanja Online Pada Masa Pandemi Covid-19," J. Teknoinfo, vol. 15 , no. 1 , p. 32 , 2021, doi: $10.33365 /$ jti.v15i1.868.

[17] S. D. Negara and E. S. Soesilowati, "E-Commerce in Indonesia: Impressive Growth but Facing Serious Challenges," no. 102, pp. 1-14, 2021.

[18] A. Alfin, "Analisis Strategi UMKM Dalam Menghadapi Krisis Di Era Pandemi COVID-19," J. Inov. Penelit., vol. 1, no. 8 SE-Articles, Dec. 2020, doi: 10.47492/jip.v1i8.280.

[19] P. I. Triyogo, S. Sasmoko, A. S. Bramantoro, and B. Agustinus, "E-Commerce Readiness of Creative Industry During the COVID-19 Pandemic in Indonesia," J. Asian Financ. Econ. Bus., vol. 8, no. 3, pp. 865-873, Mar. 2021, doi: 10.13106/JAFEB.2021.VOL8.NO3.0865.

[20] I. Suprayogo and Tobroni, Metodologi Penelitian Kualitatif. Bandung: Remaja Rosda Karya, 2011.

[21] N. K. Denzin and Y. S. Lincoln, Handbook of Qualitative Research, Terjemahan. Yogyakarta: Pustaka Pelajar, 2009.

[22] D. McQuail, Teori Komunikasi Massa Mcquail, 6th ed. Jakarta: Salemba Humanika, 2011.

[23] M. Abebe, "Electronic commerce adoption, entrepreneurial orientation and small- and mediumsized enterprise (SME) performance," J. Small Bus. Enterp. Dev., vol. 21, no. 1, pp. 100-116, Jan. 2014, doi: 10.1108/JSBED-10-2013-0145.

[24] A. Shahzad, R. Hassan, I. Abdullah, A. Hussain, and M. Fareed, "COVID-19 Impact On ECommerce Usage: An Empirical Evidence From Malaysian Healthcare Industry," Humanit. Soc. Sci. Rev., vol. 8, pp. 599-609, May 2020, doi: $10.18510 /$ hssr.2020.8364.

[25] I. As'ad and I. Sentosa, “An Empirical Study of ECommerce Implementation among SME in Indonesia," Int. J. Indep. Res. Stud., vol. 1, no. 1, pp. 13-22, 2012.

[26] N. A. M. Luong and L. Wang, "Factors Influencing E-commerce Usage within Internationalisation," Master's Thesis 30 Credit. Dep. Bus. Stud. Uppsala Univ. Spring Semester 2019, 2019.

[27] M. W. Hasanat, F. A. S. Ashikul Hoque, P. Mashrekha Anwar, Dr., A. B. A. Hamid, and Prof. Dr. Huam Hon Tat, "The impact of coronavirus on business continuity planning," Asian J. Multidiscip. Stud., vol. 3, no. 1, pp. 85-90, 2020, [Online]. Available: https://searchdisasterrecovery.techtarget.com/Theimpact-of-coronavirus-on-business-continuityplanning?track $=\mathrm{NL}$ $1822 \& \mathrm{ad}=932824 \& \mathrm{src}=932824 \&$ asrc $=$ EM_NLN $124631071 \& u t m \_$medium $=E M \& u t m \_s o u r c e=N L$ N\&utm_campaign $=20200310$ Is your business continuity plan. 